\title{
Higher Endogenous Erythropoietin Levels in Hemodialysis Patients with Hepatitis C Virus Infection and Effect on Anemia
}

\author{
Karima Boubaker'1, Madiha Mahfoudhi' ${ }^{*}$, Amel Gaieb Battikh1', Azza Bounemra², \\ Chokri Maktouf ${ }^{3}$, Adel Kheder ${ }^{1}$ \\ ${ }^{1}$ Department of Internal Medicine A, Charles Nicolle Hospital, Tunis, Tunisia \\ ${ }^{2}$ Cellular Immunology, Blood Transfusion Center, Tunis, Tunisia \\ ${ }^{3}$ Nuclear Medicine and Clinical Research Department, Pasteur institute, Tunis, Tunisia \\ Email: ${ }^{*}$ madiha mahfoudhi@yahoo.fr
}

Received 18 March 2015; accepted 22 May 2015; published 25 May 2015

Copyright (C) 2015 by authors and Scientific Research Publishing Inc.

This work is licensed under the Creative Commons Attribution International License (CC BY). http://creativecommons.org/licenses/by/4.0/

(c) (i) Open Access

\section{Abstract}

Study for influence of chronic Hepatitis C (HCV) on endogenous erythropoietin production and on anemia in dialysis patients remains inconclusive. We hypothesize that chronic hemodialysis patients with co-existing Hepatitis $C$ infection will have higher hemoglobin levels than chronic hemodialysis patients without hepatitis $C$ infection. Secondly, we hypothesize that the higher hemoglobin levels will be associated with higher erythropoietin levels. Therefore we conducted a cross-sectional study of chronic hemodialysis patients with and without hepatitis $\mathrm{C}$ infection and evaluated associations with hemoglobin and erythropoietin levels. Our primary outcome was level of hemoglobin. Secondary outcome included association of hemoglobin and erythropoietin levels. 57 chronic hemodialysis patients (33 male, 24 female, mean age $46.05 \pm 12.7$ years) were included. The mean time spent on hemodialysis was $7.16 \pm 6.2$ years. None of the patients received any recombinant EPO therapy. Biochemical analyses include ALT, AST, Albumin, C-Reactive Protein, cholesterol levels and complete blood counts. Iron status of patients (transferrin saturation and serum ferritin levels) and parathyroid hormone were measured. Endogenous EPO serum levels were measured by a standardized enzyme-linked immunoassay. 23 of the hemodialysed patients $(38.5 \%)$ were HCV $(+)$. There was no difference in age, sex, distribution of primary renal diseases, iron status, albumin, C-Reactive-Protein and parathyroid hormone levels between HCV (+) and (-) patients. Mean duration time on dialysis was higher in HCV (+) than HCV (-) patients. Hemoglobin levels were similar between study groups. However serum endogenous erythropoietin levels were significantly higher in HCV (+) patients than HCV (-) patients $(19.6 \pm 10 \mathrm{mUI} / \mathrm{ml}$ vs $7.8 \pm 7.7$ $\mathrm{mUI} / \mathrm{ml}, \mathrm{p}=0.03$ ). No correlation has been found between the severity of anemia and HCV infection. However, HCV (+) hemodialysed patients had higher serum endogenous erythropoietin levels *Corresponding author. 
as compared to HCV (-) patients. Further studies are needed to clarify why high endogenous erythropoietin level does not improve anemia in HCV infected hemodialysis patients.

\author{
Keywords
}

\author{
Anemia, Hepatitis C, Hemodialysis, Erythropoietin
}

\title{
1. Introduction
}

Hepatitis C virus (HCV) was cloned and identified as the major cause of parenterally transmitted non- $\mathrm{A}$ and non-B hepatitis in 1989 [1]. In hemodialysis patients, HCV infection is the most common cause of acute and chronic hepatitis and it increases risk for death. In this population, HCV infection is mainly handily transmitted since transmission by blood product transfusion is virtually eliminated with the screening of blood products for anti-HCV [2] [3]. The prevalence of anti-HCV using standardized enzyme-linked immunoassay among dialysis patients is variable in different countries. Study for influence of chronic HCV on anemia in dialysis patients remains inconclusive. Lessened anemia was observed in chronic HCV positive hemodialysis patients, which demanded less erythropoietin (EPO) dose than in HCV negative hemodialysis patients [4]-[8]. On the other hand, increased endogenous EPO production was reported in hemodialysis patients with hepatitis virus infections [6] [9] [10].

In this study, we hypothesize that chronic hemodialysis patients with co-existing Hepatitis C infection will have higher hemoglobin levels than chronic hemodialysis patients without hepatitis C infection. Secondly, we hypothesize that the higher hemoglobin levels will be associated with higher erythropoietin levels. Therefore we conducted a cross-sectional study in our department of chronic hemodialysis patients with and without hepatitis $\mathrm{C}$ infection and evaluated associations with hemoglobin and erythropoietin levels. Our primary outcome was level of hemoglobin. Secondary outcomes included association of hemoglobin and erythropoietin levels.

\section{Material and Methods}

One hundred thirty two chronic hemodialysis patients were followed-up in our hemodialysis unit in 2006. Demographic data were collected including age and sex. Duration of hemodialysis, Anti-HCV antibody, Hepatitis B surface antigen and antibody were investigated in all patients. Laboratory parameters are done retrospectively before patients identified and investigated complete blood count, iron status (transferrin saturation (TSAT) and serum ferritin levels) and parathyroid hormone (PTH) levels. As a marker of inflammation, serum C-reactive protein (CRP) was measured. Functional iron deficiency (defined on the basis of TSAT $<20 \%$ and serum ferritin $<100 \mathrm{ng} / \mathrm{ml}$ ) was treated by intravenous iron saccharate treatment. None of the patients received any recombinant EPO therapy because this treatment is not present in our country for economical reasons.

Inclusion criteria were a stable clinical state, hemodialysis duration 12 hours since at least 12 weeks, TSAT between $20 \%$ and $50 \%$ and serum ferritin between 100 and $800 \mathrm{ng} / \mathrm{ml}$.

Exclusion criteria were blood transfusion, major surgery and massive blood loss with worsening anemia in the preceding 3 months, treatment with angiotensin II receptor blocker or any drug containing aluminum.

Fifty seven chronic hemodialysis patients (33 male, 24 female, mean age $46.05 \pm 12.7$ years) were enrolled in the cross-sectional study. Primary renal diseases were primary glomerular disease in 20 cases, diabetic nephropathy in 3 cases, secondary amyloidosis in 1 case, lupus nephritis in 2 cases, hypertensive nephropathy in 6 cases, interstitial nephritis in 10 cas, polycystic kidney disease in 3 cases and unknown nephropathy in 12 cases. The mean time spent on hemodialysis was $7.16 \pm 6.2$ years ( 1 - 33 ans).

Dialyses were performed for 4 hours, three times a week with carbonate-containing dialysate bath using a double-needle technique with native arteriovenous fistulas. Blood flow rate was $250-300 \mathrm{ml} / \mathrm{min}$ with a dialysate flow of $500 \mathrm{ml} / \mathrm{min}$. All patients were dialyzed with polysulfone membranes which were discarded after dialysis session. All patients were taking folic acid, vitamins and calcium carbonate, and some of them were treated with antihypertensive drugs.

Regarding coexisting infectious, autoimmune or neoplastic diseases, 2 patients had systemic lupus erythematosus, 1 patient had Tuberous sclerosis and 1 patient had Epidermolysis Bullosa Simplex. One patient with sec- 
ondary amyloidosis had a history of pleural tuberculosis. These diseases were clinically inactive and not requiring therapy while on dialysis. None of the patients with HCV infection undergo treatment for hepatitis C.

Complete blood counts and blood chemistries were performed on an auto analyzer using routine laboratory methods. TSAT was calculated by expressing serum iron as a percentage of plasma total iron-binding capacity.

$$
\operatorname{TSAT}(\%)=(\text { iron/total iron binding capacity }) \times 100 \text {. }
$$

Endogenous EPO serum levels were measured by a standardized enzyme-linked immunoassay.

Biochemical analyses including ALT, AST, Albumin and cholesterol levels were measured.

Only one study visit was made.

Statistical analysis was performed using Statview logician. Data were presented as mean \pm standard deviation. Two groups were compared for numerical variables by using unpaired Student's test. For non-numerical data, Chi2-tests were used for the comparison of the two groups. The criterion of statistical significance was $p<0,05$.

\section{Results}

Demographic features and the results of biochemical analysis, hemogram and parameters related to iron status are shown in Table 1 and Table 2. There was no difference in age, sex, distribution of primary renal diseases,

Table 1. Epidemiologic and clinical data of patients.

\begin{tabular}{|c|c|c|c|}
\hline & Anti-HCV (+) $(n=23)$ & Anti-HCV $(-)(n=34)$ & Statistics (p) \\
\hline Gender (Males/Females) & $14 / 9$ & $19 / 15$ & 0.916 \\
\hline Age (years) & $46.4 \pm 11.8$ & $45.8 \pm 13.4$ & 0.8676 \\
\hline Time on hemodialysis (years) & $10.6 \pm 7.7$ & $4.5 \pm 3$ & 0.0022 \\
\hline Primary renal disease & 17 & 28 & 0.1055 \\
\hline Primary glomerular disease & 8 & 12 & \\
\hline Diabetic nephropathy & 0 & 3 & \\
\hline Secondary amyloidosis & 1 & 0 & \\
\hline Lupus nephritis & 2 & 0 & \\
\hline Interstitial nephritis & 4 & 6 & \\
\hline Polycystic kidney disease & 2 & 1 & \\
\hline Hypertensive nephropathy & 0 & 6 & \\
\hline Unknown & 6 & 6 & \\
\hline Vasoactive drug & 10 & 17 & 0.6291 \\
\hline Calcium channel antagonist & 7 & 10 & 0.057 \\
\hline$\beta$-blocker & 0 & 3 & 0.297 \\
\hline
\end{tabular}

Values are given as mean \pm standard deviation.

Table 2. Biological and viral data of patients.

\begin{tabular}{cccc}
\hline Viral hepatitis B seropositive & 1 & 4 & 0.615 \\
Albumin (g/l) & $39.7 \pm 4.1$ & $40.7 \pm 3.9$ & 3.926 \\
C-Reactive-Protein (mg/l) & $4.07 \pm 2.7$ & $5.25 \pm 4.6$ & 0.3349 \\
AZT (IU/) & $22.2 \pm 11.4$ & $18.6 \pm 19$ & 0.528 \\
ALT (IU/) & $23.6 \pm 21.7$ & $20.1 \pm 29.7$ & 0.7 \\
Ferritin (g/dl) & $261.5 \pm 146.9$ & $352.2 \pm 214.1$ & 1.894 \\
TSAT (\%) & $32.7 \pm 10.5$ & $28.4 \pm 10.7$ & 0.3353 \\
Cholesterol (mmol/) & $3.7 \pm 0.97$ & $3.7 \pm 0.89$ & 0.7562 \\
PTH (pg/ml) & $217.54 \pm 150$ & $186.8 \pm 129.8$ & 0.5827 \\
\hline
\end{tabular}

Values are given as mean \pm standard deviation. 
albumin, PTH, AST, ALT serum, ferritin levels, TSAT and CRP levels between HCV (+) and HCV (-) hemodialysis patients. Mean duration time on dialysis was higher in $\mathrm{HCV}(+)$ than $\mathrm{HCV}(-)$ patients.

Hemoglobin levels were similar between study groups. However serum endogenous erythropoietin levels were significantly higher in $\mathrm{HCV}(+)$ patients than $\mathrm{HCV}(-)$ patients $(19.6 \pm 10 \mathrm{mUI} / \mathrm{ml}$ vs $7.8 \pm 7.7 \mathrm{mUI} / \mathrm{ml}, \mathrm{p}$ $=0.03$ ) (Table 3).

\section{Discussion}

In this study, no correlation has been found between the severity of anemia and HCV infection. However, endogenous EPO levels were significantly higher in anti-HCV positive hemodialysis patients than in HCV-negative patients.

Patients in maintenance hemodialysis are at increased risk of acquiring HCV infection and consequently have a higher prevalence than general population [11], but large variations in HCV infection occur among dialysis units in different geographic areas. For example, the prevalence of HCV infection among dialysis patients in different European and Mediterranean countries varied between 2\% and 63\% [3]. In Tunisia, prevalence of HCV infection was $20.4 \%$ among dialysis patients in 2006 and $11.7 \%$ in 2008 according to immunology laboratory research of Tunisia. In our department, prevalence was $19 \%$ in 2006.

In literature was reported that the time on hemodialysis dialysis was significantly longer among HCV-positive patients than HCV-negative patients [12]. The risk of acquiring HCV infection on hemodialysis has been estimated at $10 \%$ per year [13] [14]; so that the time on hemodialysis is an independent risk factor for acquiring HCV infection [15]. Our data were concordant with literature data.

In this study, we did not report any significantly difference in hemoglobin level between HCV-positive and -negative hemodialysis patients. None of the patients with HCV infection undergo treatment for hepatitis $\mathrm{C}$ as some of the drugs can cause anemia. Our result was consistent with some reports [6]. However, in other reports hemoglobin was significantly higher in HCV-positive or after hepatitis B virus infection in hemodialysis patients [10] [16]-[19].

Endogenous EPO is mainly produced by kidneys [20]. Ability of the EPO production is well preserved in end-stage-renal disease patients [21]. In fact, serum EPO level despite severe anemia or hypoxia, is similar in end-stage-renal disease patients and in normal subjects (respectively $37.4 \pm 15.3 \mathrm{mU} / \mathrm{ml}$ and $24-42 \mathrm{mU} / \mathrm{ml}$ ) [21] [22]. In dialysis patients, anemia is ascribed mainly to reduced sensitivity of bone marrow to EPO, probably as a result of retention of uremic toxins and inhibitors of erythropoiesis.

In our study, patients did not received exogenous EPO and than endogenous EPO levels measurement was possible.

We demonstrated that HCV-positive hemodialysis patients had higher endogenous EPO levels compared to HCV-negative patients. There are few data on serum endogenous EPO in hemodialysis patients with chronic viral infection with HCV or hepatitis B virus [5] [6]. Since 1980, some authors reported in hemodialysis or normal subjects, an increase in the hepatic synthesis of EPO by regenerating hepatocytes after viral and toxic cytolysis or hepatocellular carcinoma [10] [18] [23]. Hepatic production of EPO is maximal in experimental animals, during liver regeneration or anemia and is the main source for production of endogenous EPO in the fetal stage [5] [16] [18] [24] [25]. High endogenous EPO level in infected HCV patients may be explained by hepatic synthesis.

In our study, high endogenous EPO level does not improve anemia in HCV-positive patients perhaps because the level of EPO in these patients was very low to improve anemia. On the other hand, some authors reported suppression of EPO by humeral factors, possibly cytokines or growth factors [26] [27].

Table 3. Comparison of the anti-HCV-negative and -positive patients levels of hemoglobin and endogenous erythropoietin.

\begin{tabular}{cccc}
\hline & Anti-HCV $(-)(\mathbf{n}=\mathbf{2 3})$ & Anti-HCV $(+)(\mathbf{n}=\mathbf{3 4})$ & Statistics \\
\hline Hemoglobin (g/d) & $9.7 \pm 3.01$ & $9.3 \pm 2.56$ & 0.583 \\
Mean corpuscular volume & 86.9 & 86.9 & 0.972 \\
Erythropoïetin level (mU.I./ml) & $19.6 \pm 10$ & $7.8 \pm 7.7$ & 0.0347 \\
\hline
\end{tabular}

Values are given as mean \pm standard deviation. 
Among the limitations of this study, we cite the reduced number of the sample. The initial values of the endogenous EPO before HCV infestation was also missing in our study. This has prevented us from performing a comparison before and after the occurrence of hepatitis C. The findings of this study can't be formally considered. Only a prospective study on more extended sample could draw objective and interesting conclusions.

\section{Conclusion}

In our hemodialysis patients no correlation has been found between the severity of anemia and HCV infection. However, higher endogenous EPO levels were observed in these patients explained probably by hepatic synthesis. Further studies are needed to clarify other causes of higher endogenous EPO levels and to define etiologies of EPO resistance in HCV-pstositive hemodialysis patients.

\section{Conflicts of Interest}

The authors declare no conflict of interest.

\section{References}

[1] Kuo, G., Choo, K.L., Alter, H.J., Gitnick, G.L., Redeker, A.G., Purcell, R.H., et al. (1989) An Assay for Circulating Antibodies to a Major Etiologic Virus of Human Non-A, Non-B Hepatitis. Science, 244, 362-364. http://dx.doi.org/10.1126/science.2496467

[2] Pereira, B.J. (1999) Hepatitis C Virus Infection in Dialysis: A Continuing Problem. Artificial Organs, 23, 51-60. http://dx.doi.org/10.1046/j.1525-1594.1999.06274.x

[3] Akpolat, T., Turkish Multicentre CAPD Study Group (TULIP) (2001) CAPD: A Control Strategy to Prevent Spread of HCV Infection and End Stage Renal Disease (Short Reports). Peritoneal Dialysis International, 21, 77-79.

[4] Di Bisceglie, A.M., Axiotis, C.A., Hoofnagle, J.H. and Bacon, B.R. (1992) Measurement of Iron Status in Patients with Chronic Hepatitis. Gastroenterology, 102, 2108-2113.

[5] Radovic, M., Jelkmann, W., Djukanovic, L. and Ostric, V. (1999) Serum Erythropoietin and Interleukin-6 Levels in Hemodialysis Patients with Hepatitis Virus Infection. Journal of Interferon \& Cytokine Research, 19, 69-73. http://dx.doi.org/10.1089/107999099314072

[6] Altintepe, L., Kurtoglu, E., Tonbul, Z., Yeksan, M., Yildiz, A. and Türk, S. (2004) Lower Erythropoietin and Iron Supplementation Are Required in Haemodialysis Patients with Hepatitis C Virus Infection. Clinical Nephrology, 61, 347-351. http://dx.doi.org/10.5414/CNP61347

[7] Lin, Y.L., Lin, C.W., Lee, C.H., Lai, I.C., Chen, H.H. and Chen, T.W. (2008) Chronic Hepatitis Ameliorates Anemia in Haemodialysis Patients. Nephrology, 13, 289-293. http://dx.doi.org/10.1111/j.1440-1797.2008.00937.x

[8] Khurana, A., Nickel, A.E., Narayanan, M. and Foulks, C.J. (2008) Effect of Hepatitis C Infection on Hemodialysis Patients. Hemodialysis International, 12, 94-99. http://dx.doi.org/10.1111/j.1542-4758.2008.00248.x

[9] Brown, S., Caro, J., Erslev, A.J. and Murray, T.G. (1980) Spontaneous Increase in Erytropoietin and Hematocrit Value Associated with Transient Liver Enzyme Abnormalities in an Anephric Patient Undergoing Hemodialysis. The American Journal of Medicine, 68, 280-284. http://dx.doi.org/10.1016/0002-9343(80)90367-8

[10] Brown, S., Caro, J., Erslev, A.J. and Murray, T.G. (1999) Impact of Hepatitis B and C Virus on Kidney Transplantation Outcome. Hepatology, 29, 257-263. http://dx.doi.org/10.1002/hep.510290123

[11] Natov, S.N. and Pereira, B.J.G. (1994) Hepatitis C Infection in Patients on Dialysis. Seminars in Dialysis, 7, 360-368. http://dx.doi.org/10.1111/j.1525-139X.1994.tb00855.x

[12] Weiner, A.J., Kuo, G., Bradley, D.W., Bonino, F., Saracco, G., Lee, C., et al. (1990) Detection of Hepatitis C Viral Sequences in Non A, Non-B Hepatitis. The Lancet, 335, 1-3. http://dx.doi.org/10.1016/0140-6736(90)90134-Q

[13] Hardy, N.M., Sandroni, S., Danielson, S. and Wilson, W.J. (1992) Antibody to Hepatitis C Virus Increases with the Time on Dialysis. Clinical Nephrology, 38, 44-48.

[14] Medici, G., Depetri, G.C. and Mileti, M. (1992) Anti-Hepatitis C Virus Positivity and Clinical Correlations in Hemodialyzed Patients. Nephron, 61, 363-364. http://dx.doi.org/10.1159/000186945

[15] Pereira, B.J. and Levey, A.S. (1999) Hepatitis C Virus Infection in Dialysis and Renal Transplantation. Kidney International, 51, 981-999. http://dx.doi.org/10.1038/ki.1997.139

[16] Chan, N., Barton, C.H., Mirahmadi, M.S., Gordon, S. and Vaziri, N.D. (1984) Erythropoiesis Associated with Viral Hepatitis in End-Stage Renal Disease. The American Journal of the Medical Sciences, 287, 56-57. http://dx.doi.org/10.1097/00000441-198401000-00017 
[17] Pololi-Anagnostou, A., Westenfelder, C. and Anagnostou, A. (1981) Marked Improvement of Erythropoiesis in an Anephric Patient. Nephron, 29, 277-279. http://dx.doi.org/10.1159/000182389

[18] Simon, P., Meyrier, A., Tanquerel, T. and Ang, K.S. (1980) Improvement of Anaemia in Haemodialyzed Patients after Viral or Toxic Hepatic Cytolysis. British Medical Journal, 280, 892-894. http://dx.doi.org/10.1136/bmj.280.6218.892

[19] Sahin, I., Arabaci, F. and Sahin, H.A. (2003) Does Hepatitis C Virus Infection Increase Hematocrit and Haemoglobin Levels in Hemodialyzed Patients? Clinical Nephrology, 60, 401-404. http://dx.doi.org/10.5414/CNP60401

[20] Jelkmann, W. (1992) Erythropoietin: Structure, Control of Production and Function. Physiological Reviews, 72, 449489.

[21] Zadrazil, J., Bachleda, P. and Zahálková, J. (1997) Endogenous Erythropoietin in Patients on Regular Dialysis Therapy. Vnitrní Lékarství, 43, 649-654.

[22] Kato, A., Hishida, A., Kumagai, H., Furuya, R., Nakajima, T. and Honda, N. (1994) Erythropoietin Production in Patients with Chronic Renal Failure. Renal Failure, 16, 645-651. http://dx.doi.org/10.3109/08860229409044892

[23] Kew, M.C. and Fisher, J.W. (1986) Serum Erythropoietin Concentrations in Patients with Hepatocellular Carcinoma. Cancer, 58, 2485-2488. http://dx.doi.org/10.1002/1097-0142(19861201)58:11<2485::AID-CNCR2820581122>3.0.CO;2-N

[24] Brox, A.G., Zhang, F., Guyda, H. and Gagnon, R.F. (1996) Subtherapeutic Erythropoietin and Insulin-Like Growth Factor-1 Correct the Anemia of Chronic Renal Failure in the Mouse. Kidney International, 50, 937-943. http://dx.doi.org/10.1038/ki.1996.394

[25] Bondurant, M.C. and Koury, M.J. (1985) Anemia Induces Accumulation of Erythropoietin mRNA in the Kidney and Liver. Molecular and Cellular Biology, 6, 2731-2733.

[26] Birgegård G. (1989) Erythropoiesis and Inflammation. Contrib Nephrol, 76, 330-339; discussion 339-341.

[27] Mecans, R.T. and Krantz, S.B. (1992) Progress in Understanding the Pathogenesis of the Anemia of Chronic Disease. Blood, 80, 1639-1647.

\section{List of Abbreviations}

HCV: Hepatitis C virus

EPO: Erythropoietin

TSAT: Transferrin saturation

PTH: Parathyroid hormone

CRP: C-reactive protein

ALT: Alanine aminotransferase

AST: Aspartate aminotransferase 